\title{
Prioritas Pembangunan di Kabupaten Kepulauan Meranti, Provinsi Riau, Indonesia.
}

\section{Hayuning Anggrahita ${ }^{1}$, Guswandi ${ }^{2}$, Nabila Dety Novia Utami ${ }^{3}$}

${ }^{1}$ Departemen Geografi, Fakultas MIPA, Universitas Indonesia, Indonesia

${ }^{2}$ Fakultas Ekonomi, Universitas Sultan Ageng Tirtayasa, Indonesia

Email Koresponden: hayuning.anggrahita@gmail.com

Diterima: Januari 2018/Refisi: Maret 2018 Disetujui: September 2018

( 2018 Fakultas Geografi UGM dan Ikatan Geograf Indonesia (IGI)

\begin{abstract}
Abstrak Kabupaten Kepulauan Meranti terletak berdekatan dengan Batam yang dikembangkan sebagai pusat pertumbuhan yang disebut sebagai Kawasan Perdagangan Bebas dan Pelabuhan Bebas. Pengembangan Batam tersebut diharapkan memberikan dampak sebar bagi wilayah sekitarnya (hinterland), khususnya Meranti. Berdasarkan latar belakang tersebut, penelitian ini bertujuan untuk mengetahui dampak posisi Meranti tersebut terhadap pembangunannya. Selain itu, penelitian ini bertujuan untuk menentukan sektor basis apa yang sebaiknya diprioritaskan untuk dikembangkan dan dimana sebaiknya sektor tersebut dikembangkan di Meranti. Untuk menjawab pertanyaan tersebut, penelitian ini menggunakan metode kuantitatif dengan menggunakan analisis gravitasi dan location quotient. Selain itu, analisis spasial dilakukan untuk menentukan lokasi pengembangan sektor-sektor basis di Meranti. Kemudian, hasil tersebut dibandingkan dengan rencana pembangunan (RPJP dan RPJMD Kabupaten Meranti). Penelitian ini menemukan bahwa pengembangan Batam sebagai pusat pertumbuhan belum mampu memberikan dampak sebar signifikan bagi Meranti sehingga perlu di dikembangkan sektor basis berikut: transportasi dan pergudangan, pertanian, dan industri pengolahan.
\end{abstract}

Kata kunci: pusat pertumbuhan, sektor basis, pembangunan wilayah, pembangunan ekonomi, Kabupaten Kepulauan Meranti.

Abstract Meranti Island Regency is located near to Batam, which is developed as a growth center called Free Trade Zone and Free Port. Batam development as a growth pole is expected to spread to its hinterland, including Meranti. Based on the previous background, this study aims to determine the impacts of Meranti's position toward its development. This study also aims to determine what sectors should be prioritized, and where its location should be developed. To answer those questions, this study uses quantitative methods with gravity model and location quotient analyses. Besides, it uses spatial analysis to determine the location of leading sectors. Those results are compared with Meranti Government's development planning. This study found that Batam development as a growth pole has not delivered yet significant impacts to Meranti. The leading sectors that should be developed in Meranti are transportation and warehousing, agricultural, and manufacturing sectors.

Keywords: growth pole, leading sector, regional development, economic development, Meranti Isaland Regency.

\section{PENDAHULUAN}

Kabupaten Kepulauan Meranti merupakan kabupaten di pesisir timur Provinsi Riau. Kabupaten tersebut merupakan pemekaran dari Kabupaten Bengkalis dan merupakan salah satu kabupaten otonomi baru pada tahun 2009 yang dibentuk berdasarkan UU No. 12 Tahun 2009. Kabupaten Kepulauan Meranti terletak berdekatan dengan pengembangan Batam sebagai Kawasan Perdagangan Bebas dan Pelabuhan Bebas (KPBPB) yang diatur melalui Peraturan Pemerintah Nomor 46 tahun 2007 dan bagian yang tidak terpisahkan dari Free Trade Zone Batam, Bintan dan Karimun (FTZ-BBK) yang merupakan usaha untuk mempercepat pengembangan ekonomi di wilayah tertentu yang bersifat strategis bagi pengembangan ekonomi nasional (Syahza dan Suarman, 2013).

Pengembangan Batam sebagai pusat pertumbuhan tersebut diharapkan dapat menyebar atau memberikan imbas bagi wilayah sekitarnya (hinterland), khususnya Kabupaten Kepulauan Meranti. Secara umum, teori pusat pertumbuhan (growth pole theory) menekankan pada daya tarik dari aktivitas dan pemusatan pertumbuhan ekonomi pada sebuah kutub, yang kemudian dapat mendorong pembangunan pada daerah-daerah sekitarnya (Bere et al, 2014). Kemudian, menurut Myrdal (1957) dan Hirschman (1958) dalam Potter (1985), pusat pertumbuhan tersebut dapat memberikan dampak positif dan negatif bagi wilayahwilayah hinterland yaitu spread effect dan backwash effect sebagai bentuk pengaruh penjalaran dari pusat pertumbuhan ke daerah sekitar. Spread effect (dampak sebar) didefinisikan sebagai suatu pengaruh yang menguntungkan (favorableeffect), yang mencakup aliran kegiatan-kegiatan investasi dari pusat pertumbuhan ke daerah sekitar. Sedangkan backwash effect (dampak balik) didefinisikan sebagai pengaruh yang merugikan (infavorable effect) yang mencakup aliran manusia dan modal dari wilayah sekitar atau pinggiran ke wilayah inti, sehingga mengakibatkan berkurangnya kapasitas pembangunan hinterland untuk dapat mengimbangi 
perkembangan yang terjadi di wilayah inti. Jika besarnya pengaruh dari backwash effect lebih besar dibandingkan dengan spread effect di wilayah-wilayah dapat menyebabkan terjadinya ketimpangan regional (Sheppard, 2017). Selain itu, tidak semua tempat dapat dijadikan pusat pertumbuhan sehingga masing-masing wilayah perlu mengembangkan spesialisasi produksi yang menjadi sektor basis (leading sector) dalam wilayahnya (Potter 1985).

Berdasarkan latar belakang tersebut, penelitian ini bertujuan untuk menganalisis bagaimana pengaruh Batam sebagai pusat pertumbuhan terhadap Kepulauan Meranti sebagai hinterland Batam. Apakah pengembangan Batam sebagai pusat pertumbuhan dapat memberikan dampak positif terhadap pembangunan wilayah di Kepulauan Meranti? Jika belum memberikan dampak positif signifikan, pembangunan ekonomi sektor apa yang sebaiknya dikembangkan dan dimana sebaiknya sektor tersebut dikembangkan di Kepulauan Meranti?

\section{METODE PENELITIAN}

Metode yang digunakan adalah metode kuantitatif berbasis data sekunder. Untuk melihat pengaruh Batam sebagai pusat pertumbuhan terhadap Kepulauan Meranti, maka penelitian ini menggunakan analisis gravitasi yang menggambarkan seberapa besar interaksi antara dua wilayah (Putra et al, 2017; Silveira dan Dentinho, 2018) dan membandingkannya dengan interaksi wilayah antara Kabupaten Kepulauan Meranti dengan ibukota provinsinya, yaitu Pekanbaru sehingga dapat dilihat interaksi mana yang lebih kuat, apakah dengan Batam atau dengan ibukota provinsinya. Kekuatan interaksi wilayah dapat diukur dengan menggunakan rumus gravitasi sebagai berikut (Sink, 2010; Putra et al, 2017):

$$
\begin{gathered}
\mathrm{I}_{12}=\mathrm{a} . \\
\mathrm{J}_{12}{ }^{\mathrm{b}}
\end{gathered}
$$

Keterangan:

$$
\begin{array}{ll}
\mathrm{I}_{12} & =\text { Interaksi antara wilayah } 1 \text { dan } 2 \\
\mathrm{P}_{1} \text { dan } \mathrm{P}_{2}= & \text { Ukuran }(\text { size }) \text { wilayah } 1 \text { dan wilayah } 2 \\
& \text { (dalam hal ini jumlah penduduk) } \\
\mathrm{J}_{12} & =\text { Jarak antara wilayah } 1 \text { dan } 2 \\
\mathrm{a} & =\text { konstanta } \\
\mathrm{b} & =\text { friksi jarak }
\end{array}
$$

Selain itu akan dilihat apakah kedudukan strategis Kepulauan Meranti yang dekat dengan Batam memberikan dampak pada tingkat pembangunan di kabupaten tersebut. Adapun indikator tingkat pembangunan yang digunakan tidak hanya dalam bidang ekonomi tetapi juga dalam bidang sosial. Oleh karena itu, untuk melihat tingkat pembangunan di Kabupaten Kepulauan Meranti, akan digunakan dua indikator yaitu Pendapatan Daerah Regional Bruto (PDRB) dan Indeks Pembangunan Manusia (IPM). Kemudian, kedua indikator Meranti tersebut dibandingkan dengan induknya, Provinsi Riau. Data PDRB dan IPM didapatkan dari BPS Kabupaten Kepulauan Meranti dan BPS Provinsi Riau. Data tersebut kemudian dianalisis dengan analisis kuantitatif deskriptif.

Sedangkan untuk mengetahui sektor basis apa yang sebaiknya dikembangkan di Kabupaten Kepulauan Meranti, maka analisis Location Quotient (LQ) akan digunakan. LQ adalah perhitungan konsentrasi kegiatan ekonomi di suatu area dan merupakan statistik deskriptif yang paling mudah dari alat-alat analisis yang tersedia namun tetap efektif (Nagle, 2000). Tujuan LQ adalah untuk menghasilkan sebuah koefiesien untuk mengukur seberapa baik representasi suatu kegiatan ekonomi di suatu wilayah (Miller et al, 1991) melalui perbandingan relatif antara kemampuan suatu sektor di daerah yang diteliti dengan kemampuan sektor yang sama pada daerah yang menjadi acuan.

Adapun rumus perhitungan LQ adalah sebagai berikut (Sjafrizal, 2014; Morrisey, 2014; BPS Kabupaten Kepulauan Meranti, 2016):

PDRBmi / 2 PDRBm

$$
\text { LQ }=\text { PDRBsb.i / } 2 \text { PDRBsb }
$$

Keterangan:

$$
\begin{array}{ll}
\text { LQ } & : \text { Besaran Location Quotient } \\
\text { PDRBmi } & \text { PDRB sektor } i \text { di Kabupaten Kepulauan } \\
& \text { Meranti pada tahun tertentu }
\end{array}
$$

Dariperhitungan LQ, kriteria umumyang dihasilkan adalah sebagai berikut: Jika LQ > 1, disebut sektor basis dan potensial untuk dikembangkan sebagai penggerak perekonomian Kabupaten Kepulauan Meranti. Jika LQ $<1$, disebut sektor non-basis, dan kurang potensial untuk dikembangkan sebagai penggerak perekonomian. Jika LQ $=1$, maka tingkat konsentrasi suatu kegiatan ekonomi daerah sama dengan tingkat wilayah acuan.

\section{HASIL DAN PEMBAHASAN}

\section{Interaksi Wilayah}

Berdasarkan hasil perhitungan dengan menggunakan rumus gravitasi yang telah dijelaskan sebelumnya, interaksi wilayah antara Batam dan Kabupaten Kepulauan Meranti adalah sebesar 9,6 
sedangkan interaksi wilayah antara Pekanbaru dan Kabupaten Kepulauan Meranti adalah 8,78. Hasil perhitungan tersebut menunjukkan bahwa interaksi wilayah antara Kepulauan Meranti dengan Batam lebih kuat dibandingkan interaksi wilayah Kepulauan Meranti dengan ibukota provinsinya yaitu Kota Pekanbaru. Kekuatan interaksi tersebut menunjukkan bahwa aliran manusia akan lebih banyak terjadi antar Kota Batam dengan Kabupaten Kepulauan Meranti dibandingkan antara Kabupaten Kepulauan Meranti dengan ibukota provinsinya yaitu Kota Pekanbaru.

\section{Pengaruh Batam sebagai Pusat Pertumbuhan} terhadap Kabupaten Kepulauan Meranti

Setelah mengetahui bahwa interaksi antara Kabupaten Kepulauan Meranti dan Batam lebih kuat dibandingkan interaksi dengan ibukota provinsinya, maka akan dilihat bagaimana pengaruh interaksi wilayah tersebut atau dengan kata lain dengan ditetapkannya Batam sebagai pusat pertumbuhan apakah memberi dampak sebar (spread effect) yang mempengaruhi tingkat pembangunan yang dilakukan di wilayah sekitarnya, khususnya di Kabupaten Kepulauan Meranti. Adapun indikator tingkat pembangunan yang dilihat tidak hanya dalam bidang ekonomi tetapi juga dalam bidang sosial. Oleh karena itu, untuk melihat tingkat pembangunan di Kabupaten Kepulauan Meranti akan digunakan dua indikator yaitu Pendapatan Daerah Regional Bruto (PDRB) dan Indeks Pembangunan Manusia (IPM) yang kemudian dibandingkan dengan PDRB dan IPM rata-rata Provinsi Riau.

PDRB di Kabupaten Kepulauan Meranti mengalami peningkatan yaitu dari 8 trilyun rupiah pada tahun 2010 menjadi 16 trilyun rupiah pada tahun 2016. Ini menunjukan adanya pembangunan di kabupaten tersebut. Namun demikian, PDRB Kabupaten Kepulauan Meranti berada jauh di bawah rata-rata PDRB Provinsi Riau (Gambar 1). Bahkan, PDRB Kabupaten Kepulauan Meranti adalah yang terendah di Provinsi Riau (BPS Provinsi Riau, 2017).

Selain itu, kecepatan tumbuh PDRB Kabupaten Meranti 2010-2016 lebih rendah dibandingkan dengan PDRB rata-rata Provinsi Riau pada tahun tersebut. Ini menunjukan bahwa terjadi kecenderungan disparitas wilayah yang semakin tinggi antara wilayah termiskin dengan wilayah lainnya di Provinsi Riau (Gambar 1)

Ekonomi Kabupaten Kepulauan Meranti tetap tumbuh positif. Namun, laju pertumbuhannya mengalami trend penurunan yaitu dari 6,88 \% pada tahun 2011 menjadi 3,22\% pada tahun 2016 (Gambar 2).

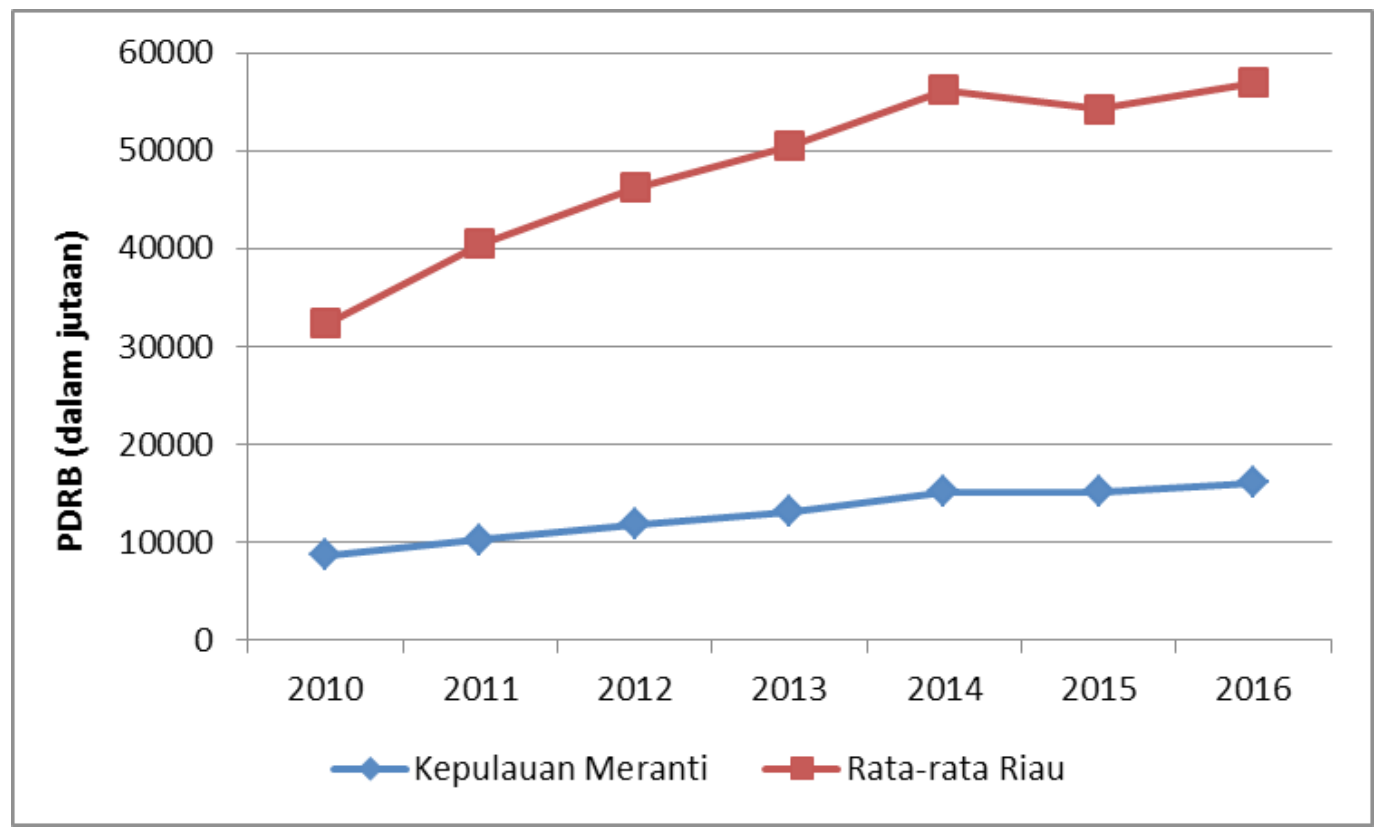

Gambar 1. PDRB Kabupaten/ Kota di Provinsi Riau Menurut Harga Berlaku Tahun 2010-2016 (BPS Provinsi Riau, 2017) 


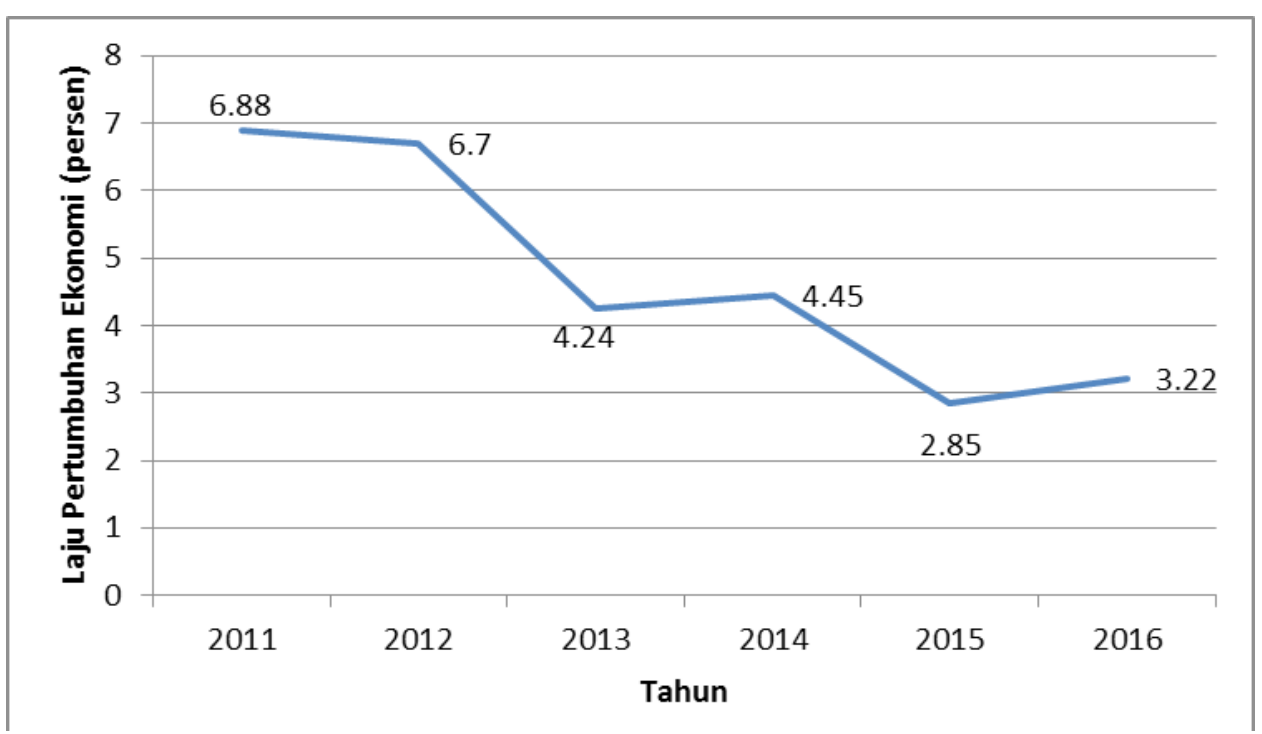

Gambar 2. Laju Pertumbuhan Ekonomi di Kabupaten Kepulauan Meranti

(BPS Kabupaten Kepulauan Meranti, 2016)

Walaupun merupakan indikator yang sangat penting, namun pertumbuhan PDRB merupakan angka agregat yang tidak dapat menggambarkan keseluruhan proses pembangunan masyarakat yang bertujuan meningkatkan kesejahteraan masyarakat. Oleh karena itu perlu melihat indikator lain untuk mendapatkan gambaran bagaimana pembangunan masyarakat yang dilakukan di Kabupaten Kepulauan Meranti. Adapun indikator yang akan dilihat adalah Indeks Pembangunan Manusia (IPM) di Kabupaten Kepulauan Meranti. IPM di Kabupaten Kepulauan Meranti menunjukkan adanya peningkatan pembangunan manusia yaitu dari 60,38 pada tahun 2011 menjadi 63,25 pada tahun 2015 (Gambar 3) dan berada pada kategori sedang (BPS Kabupaten Kepulauan Meranti, 2016). Namun demikian, IPM di Kabupaten Kepulauan Meranti lebih rendah jika dibandingkan dengan nilai rata-rata IPM di Provinsi Riau bahkan mempunyai nilai IPM yang paling rendah jika dibandingkan dengan kabupaten atau kota lainnya di Provinsi Riau.

Rendahnya nilai IPM Kabupaten Kepulauan Meranti dibandingkan dengan IPM Provinsi Riau terutama disebabkan oleh kualitas SDM yang rendah dimana rata-rata lama sekolah (RLS) di Kabupaten Kepulauan Meranti pada tahun 2016 adalah 7,26 tahun atau dengan kata lain penduduk Kabupaten Kepulauan Meranti duduk di bangku sekolah hanya 7 tahun atau sampai kelas 1 atau 2 SMP. Selain itu, jumlah penduduk miskin di Kabupaten Kepulauan Meranti adalah sebesar 61.000 jiwa dan merupakan angka kemiskinan yang paling tinggi di antara kota atau kabupaten lain di Provinsi Riau.

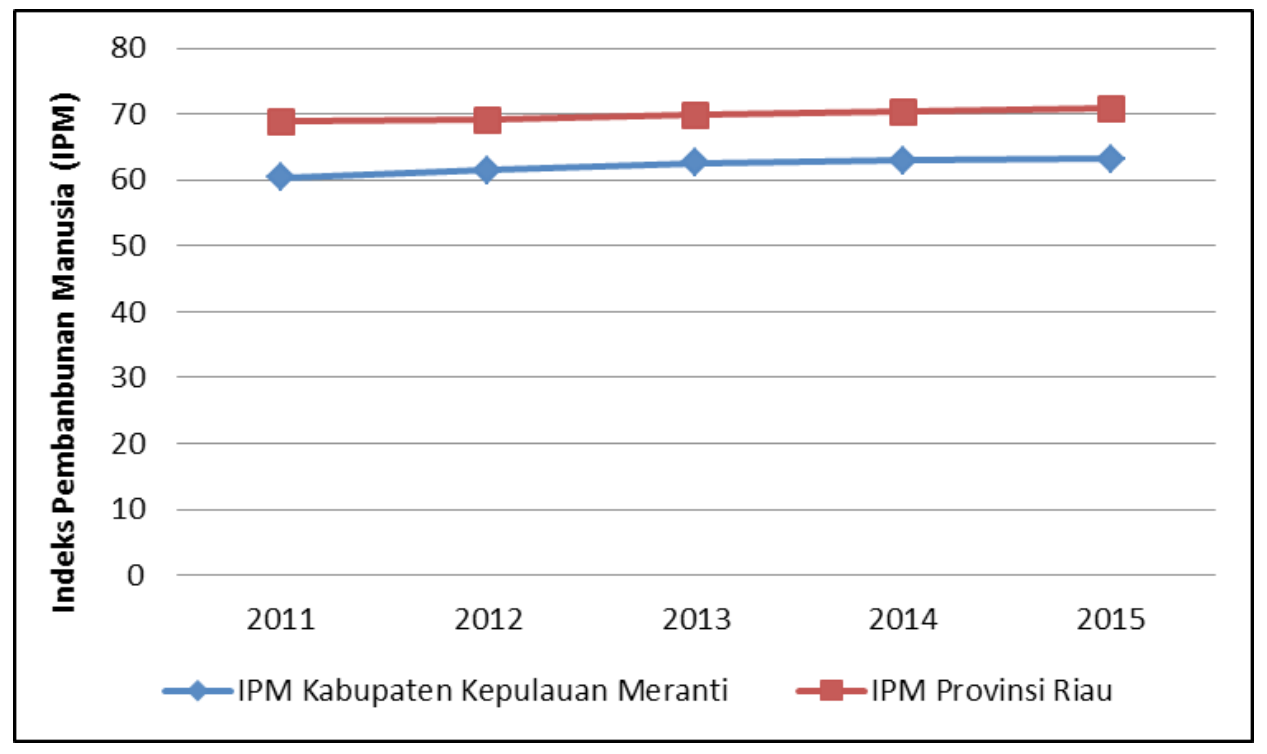

Gambar 3. Perbandingan IPM di Kabupaten Kepulauan Meranti dan Provinsi Riau (BPS Provinsi Riau, 2017) 
Hal tersebut di atas menunjukkan bahwa ditetapkannya Batam sebagai pusat pertumbuhan belum mampu memberikan dampak sebar (spread effect) yang signifikan bagi Kabupaten Kepulaun Meranti.

\section{Prioritas Pembangunan di Kabupaten Kepulauan Meranti}

Berdasarkan pembahasan pada sub-bab sebelumnya telah diketahui bahwa kedudukan strategis Kabupaten Kepulauan Meranti sebagai hinterland Batam belum mampu memberikan dampak signifikan bagi perekonomian di kabupaten tersebut. Oleh karena itu perlu ditentukan sektor basis (leading sector) yang diprioritaskan untuk dikembangkan di Kabupaten Kepulauan Meranti. Adapun penentuan sektor basis tersebut dilakukan dengan mengitung nilai LQ. Adapun nilai LQ di Kabupaten Kepulauan Meranti dapat dilihat pada Tabel 1. Berdasarkan tabel tersebut dapat dilihat bahwa ada tiga sektor yang mempunyai LQ > 1 yaitu : 1). Sektor transportasi dan pergudangan, 2). Sektor pertanian, kehutanan dan perikanan, 3). Sektor administrasi pemerintahan, pertahanan dan jaminan sosial wajib. Karena nilai LQ ketiga sektor tersebut lebih besar dari 1 maka dapat dikatakan bahwa ketiga sektor tersebut merupakan sektor basis (leading sector) di Kabupaten Kepulauan Meranti.

Hasil tersebut sejalan dengan penelitian yang dilakukan oleh Hidayat dan Darwin (2017), dimana tiga besar sektor basis di Kabupaten Kepulauan Meranti adalah: sektor transportasi dan pergudangan, sektor pertanian, kehutanan dan perikanan, dan sektor administrasi pemerintahan, pertahanan dan jaminan sosial wajib. Akan tetapi sektor industri pengolahan telah mengalami pergeseran dimana menurut Hidayat dan Darwin (2017) sektor industri pengolahan merupakan sektor basis (karena nilai LQ > 1), sedangkan pada penelitian ini sektor industri pengolahan memiliki nilai $\mathrm{LQ}=1$, sehingga dikatakan sebagai sektor potensial.

Selain mendasarkan prioritas pembangunan sektor basis secara ilmiah seperti perhitungan LQ, proses pembangunan yang berkelanjutan perlu juga memperhatikan perencanaan pembangunan yang merupakan bagian dari proses politik yang disesuaikan dengan jangka waktu pencapaian dan skala prioritas pembangunan (Kartono et al, 1998). Skala prioritas pembangunan tersebut dituangkan dalam dokumen resmi yang harus diperhatikan, yakni Rencana Pembangunan Jangka Menengah Daerah (RPJMD).

Selain mencari sektor basis yang diharapkan menjadi tulang punggung pertumbuhan ekonomi di masa datang, pemerintah juga memperhatikan serapan tenaga kerja. Demikian pula pertimbangan Pemkab Kepulauan Meranti dalam menyusun prioritas pembangunannya. Berdasarkan RPJMD Kabupaten Kepulauan Meranti Tahun 2016-2021, sektor unggulan kabupatennya adalah sebagai berikut: 1). Industri pengolahan, 2). Konstruksi, 3). Transportasi, pergudangan, dan pariwisata, 4). Jasa pendidikan, 5). Pertanian, 6). Perdagangan dan pariwisata. Pemilihan sektor-sektor tersebut didorong oleh sifat sektor-sektor tersebut yang padat tenaga kerja dan berpotensi besar menyerap tenaga kerja (BPS Kabupaten Kepulauan Meranti, 2016).

Tabel 1. Nilai LQ (Location Quotient) di Kabupaten Kepulauan Meranti

\begin{tabular}{|c|c|c|c|c|c|c|c|c|c|}
\hline \multirow{2}{*}{ No } & \multirow{2}{*}{ Lapangan Usaha PDRB } & \multicolumn{8}{|c|}{ Nilai Location Quotient (LQ) } \\
\hline & & 2010 & 2011 & 2012 & 2013 & 2014 & 2015 & 2016 & Rata-rata \\
\hline 1 & Pertanian, Kehutanan, dan Perikanan & 1.73 & 1.58 & 1.60 & 1.60 & 1.60 & 1.57 & 1.58 & 1.61 \\
\hline 2 & Pertambangan dan Penggalian & 0.69 & 0.82 & 0.83 & 0.80 & 0.76 & 0.72 & 0.70 & 0.76 \\
\hline 3 & Industri Pengolahan & 0.96 & 1.01 & 1.01 & 1.03 & 1.02 & 1.00 & 0.98 & 1.00 \\
\hline 4 & Pengadaan Listrik dan Gas & 0.91 & 0.82 & 0.76 & 0.75 & 0.62 & 0.63 & 0.69 & 0.74 \\
\hline 5 & $\begin{array}{l}\text { Pengadaan Air, Pengelolaan Sampah, } \\
\text { Limbah dan Daur Ulang }\end{array}$ & 0.30 & 0.29 & 0.29 & 0.30 & 0.33 & 0.36 & 0.37 & 0.32 \\
\hline 6 & Konstruksi & 0.43 & 0.45 & 0.43 & 0.54 & 0.61 & 0.55 & 0.53 & 0.51 \\
\hline 7 & $\begin{array}{l}\text { Perdagangan Besar dan Eceran; Reparasi } \\
\text { Mobil dan Sepeda Motor }\end{array}$ & 0.75 & 0.81 & 0.91 & 0.87 & 0.95 & 0.98 & 0.96 & 0.89 \\
\hline 8 & Transportasi dan Pergudangan & 2.52 & 2.74 & 3.02 & 3.07 & 3.11 & 2.89 & 2.78 & 2.88 \\
\hline 9 & Penyediaan Akomodasi dan Makan Minum & 0.44 & 0.48 & 0.47 & 0.51 & 0.56 & 0.57 & 0.55 & 0.51 \\
\hline 10 & Informasi dan Komunikasi & 1.05 & 0.53 & 0.66 & 0.82 & 0.91 & 0.86 & 0.82 & 0.81 \\
\hline 11 & Jasa Keuangan dan Asuransi & 0.37 & 0.38 & 0.40 & 0.36 & 0.36 & 0.35 & 0.34 & 0.36 \\
\hline 12 & Real Estate & 0.43 & 0.49 & 0.52 & 0.50 & 0.52 & 0.50 & 0.50 & 0.49 \\
\hline 13 & Jasa Perusahaan & 0.40 & 0.64 & 0.63 & 0.64 & 0.62 & 0.61 & 0.63 & 0.59 \\
\hline 14 & $\begin{array}{l}\text { Administrasi Pemerintahan, Pertahanan } \\
\text { dan Jaminan Sosial Wajib }\end{array}$ & 1.11 & 1.22 & 1.17 & 1.30 & 1.28 & 1.23 & 1.22 & 1.22 \\
\hline 15 & Jasa Pendidikan & 0.45 & 0.46 & 0.46 & 0.46 & 0.45 & 0.43 & 0.44 & 0.45 \\
\hline 16 & Jasa Kesehatan dan Kegiatan Sosial & 0.36 & 0.38 & 0.38 & 0.40 & 0.40 & 0.39 & 0.39 & 0.39 \\
\hline 17 & Jasa lainnya & 0.65 & 0.74 & 0.70 & 0.75 & 0.74 & 0.61 & 0.59 & 0.68 \\
\hline
\end{tabular}

Sumber: BPS Kabupaten Kepulauan Meranti, 2016 dan Pengolahan Data 2018. 
Irisan antara sektor-sektor yang terpilih dalam perhitungan LQ dan RPJMD Kabupaten Kepulauan Meranti 2016-2021 merupakan suatu bentuk "kompromi" antara pertimbangan ilmiah (sektor basis), dan pertimbangan kebijakan publik yang berorientasi praksis (misalnya, serapan tenaga kerja). Sedangkan yang bukan merupakan irisan, sebaiknya dikeluarkan dari prioritas pembangunan. Kepala Daerah perlu memperhatikan "kompromi" tersebut. Adapun yang menjadi irisan tersebut adalah: 1). Sektor tansportasi, pergudangan, informasi dan komunikasi; 2). Sektor pertanian dan 3). Sektor industri pengolahan.
Selain itu, "kompromi" tersebut perlu memberikan arahan dimana sektor-sektor basis tersebut sebaiknya dikembangkan. Oleh karena itu, berikut ini akan dibahas dimana sebaiknnya ketiga sektor basis tersebut dikembangkan di dalam wilayah Kabupaten Kepulauan Meranti.

Sektor basis yang pertama adalah transportasi dan pergudangan. Lokasinya ditentukan berdasarkan peta fasilitas umum Kabupaten Kepulauan Meranti (Gambar $4)$.

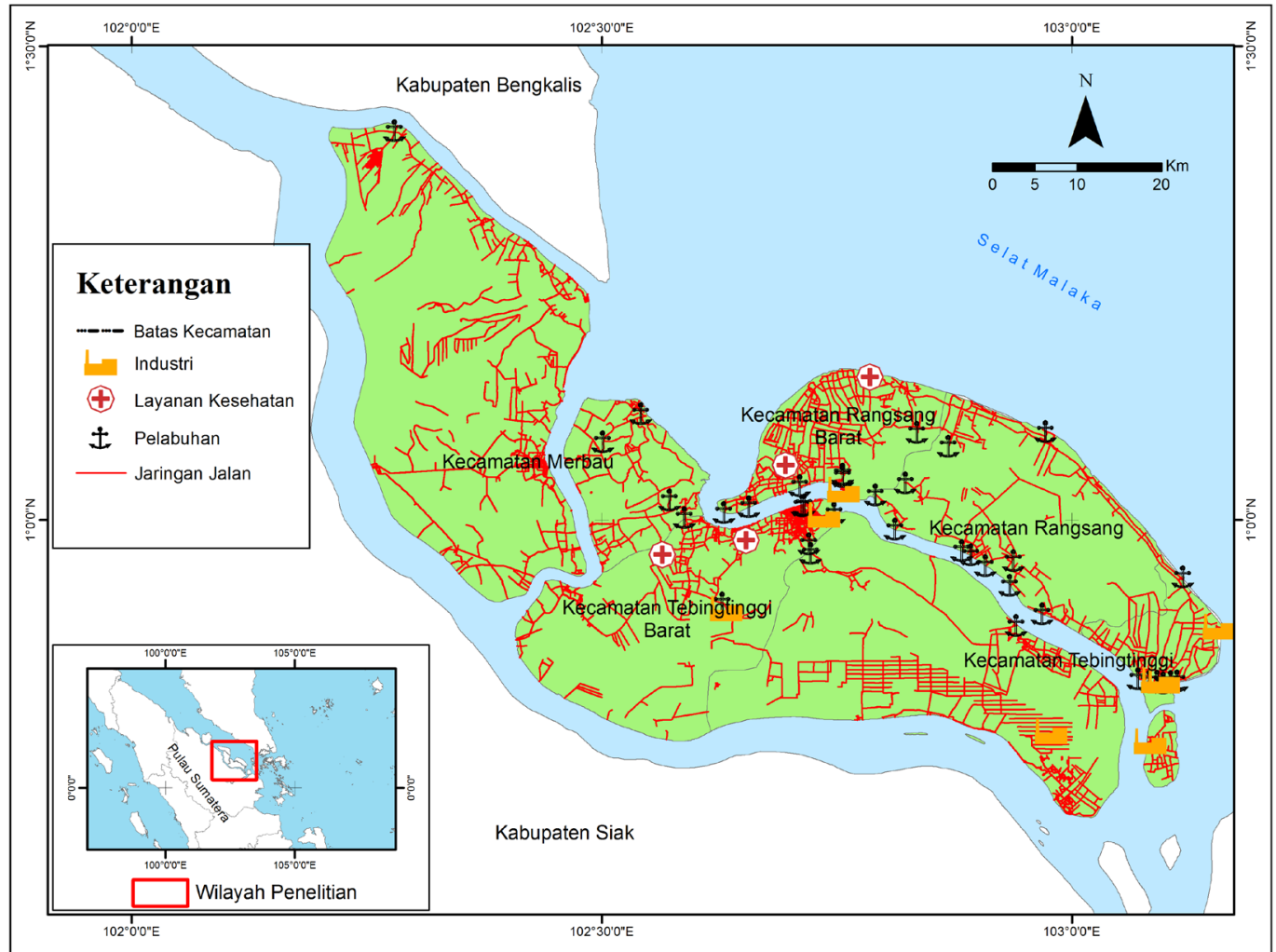

Gambar 4. Fasilitas Umum Kabupaten Kepulauan Meranti

(Peta Rupa Bumi Indonesia, Badan Informasi Geospasial, 2015)

Berdasarkan peta tersebut, sektor basis transportasi dapat diprioritaskan untuk dikembangkan di Kecamatan Tebing Tinggi Barat sebagai “jembatan” antara Riau daratan dan jalur perdagangan laut yang strategis berkaitan dengan posisi Kabupaten Kepulauan Meranti yang dekat dengan Batam dan Singapura. Hal ini dapat direalisasikan dengan pembangunan aksesibilitas utara ke selatan sebagai jalur perdagangan darat dan pengangkut produk-produk pertanian dari bagian selatan Tebing Tinggi Barat. Sesuai dengan peta fasilitas umum tersebut, jalur yang menghubungkan antara bagian selatan dan utara Kecamatan Tebing Tinggi Barat hanya satu dan sedikitnya jalan pada bagian tenggara kecamatan tersebut. Selain itu transportasi laut dan pergudangan juga dapat dikembangkan dengan membangun dan mengembangkan pelabuhan di bagian selatan Kecamatan Tebing Tinggi Barat, di bagian barat dan selatan Kecamatan Merbau (Lukit, Tanjung Padang, dan Teluk Ketapang), di bagian utara dan timur laut Kecamatan Rangsang dan di bagian timur Kecamatan Tebing Tinggi Timur (Tanjung Sari).

Sektor basisyangkedua adalah pertanian, kehutanan dan perikanan. Prioritas pengembangan pertanian yang akan dilakukan di Kabupaten Kepulauan Meranti sebaiknya disesuaikan dengan kondisi fisik kabupaten tersebut, terutama jenis tanahnya. Kabupaten Kepulauan Meranti didominasi oleh jenis tanah gambut trofik yang dibentuk oleh bahan-bahan sisa tanaman purba yang berlapis-lapis hingga mencapai ketebalan > 30 cm (Wijaya, 2012). Menurut Agus dan Subiksa (2008) 
tidak semua lahan gambut dapat dikonversi menjadi lahan pertanian dimana menurut Keputusan Presiden No 32 Tahun 1990 gambut dengan ketebalan $>3$ meter diperuntukkan sebagai kawasan konservasi karena kondisi lingkungan lahan gambut dalam yang rapuh (fragile) apabila dikonversi menjadi lahan pertanian. Lahan gambut yang dapat ditanami adalah dengan kedalaman 1,4 - 2 meter (Agus dan Subiksa, 2008).

Gambar 5 menunjukkan sebaran kedalaman lahan gambut di Kabupaten Kepulauan Meranti. Berdasarkan gambar tersebut daerah yang berwarna biru muda adalah wilayah dengan kedalaman gambut lebih dari 3 meter, yaitu wilayah bagian sebelah barat dan sebagian sebelah timur dari Kecamatan Merbau, bagian tengah Kecamatan Tebing Tinggi Barat dan Kecamatan Tebing Tinggi Timur serta bagian timur laut dan tenggara Kecamatan Rangsang. Wilayah tersebut sebaiknya dijadikan kawasan konservasi. Sedangkan wilayah lainnya dapat dimanfaatkan untuk pertanian, khususnya tanaman sagu, sawit, karet dan akasia yang berpotensi untuk ditanam di lahan gambut. Di antara keempat tanaman tersebut, tanaman sagu merupakan tanaman yang dapat ditanam pada lahan gambut yang lebih dalam karena merupakan tanaman rawa yang mempunyai toleransi paling tinggi terhadap genangan, sehingga tanaman sagu masih memungkinkan untuk ditanam pada daerah dengan kedalaman gambut 2-4 meter dengan syarat dilakukan pengkayaan lapisan tanah atau lumpur mineral (Djaenudin et al, 2003). Sedangkan tiga tanaman lain agar dapat ditanam di lahan gambut memerlukan jaringan drainase makro untuk mengendalikan tata air dalam satu wilayah dan jaringan drainase mikro untuk mengendalikan tata air di tingkat lahan. Fakta fisik tersebut kemudian perlu disesuaikan dengan Rencana Pembangunan Jangka Panjang (RPJP) Kabupaten Kepulauan Meranti Tahun 2005-2025, dimana secara khusus wilayah pengembangan pertanian dan perikanan adalah sebagai berikut: Tanjung Samak, Kecamatan Rangsang (kelapa, karet, sagu); Teluk Belitung, Kecamatan Merbau (sagu, karet dan perikanan); Tanjung Sari dan Pulau Topang, Kecamatan Tebing Tinggi Timur (sagu, karet dan perikanan); Perangas dan Desa Lemang, Kecamatan Rangsang Barat (sagu dan karet); Tanjung Padang, Kecamatan Merbau (karet, sagu dan perikanan); Kuala Merbau, Kecamatan Merbau (sagu dan karet); Alai, Kecamatan Tebing Tinggi Barat (sagu dan karet); Bandul (sagu dan karet); Meranti Bunting, Kecamatan Merbau (sagu, karet, kelapa dan perikanan); Lukit, Kecamatan Merbau bagian selatan (sagu, karet, kelapa dan perikanan); Teluk Ketapang, Kecamatan Merbau (sagu dan karet); Tanjung Peranap, Kecamatan Tebing Tinggi Barat (sagu, karet); Segomeng, Kecamatan Rangsang Barat (sagu dan karet); Sidomulyo dan Anak Penyagun (karet dan kelapa) (BPS Kabupaten Kepulauan Meranti, 2016). Jadi pada daerah Tanjung Padang dan Lukit seharusnya hanya dikembangkan untuk pertanian sagu yang cocok dengan kondisi fisik dimana kedalaman gambutnya antara $2-4 \mathrm{~m}$. Karet dan kelapa yang menurut RPJP bisa dikembangkan di kedua daerah tersebut ternyata tidak sesuai dengan kedalaman gambut tersebut.

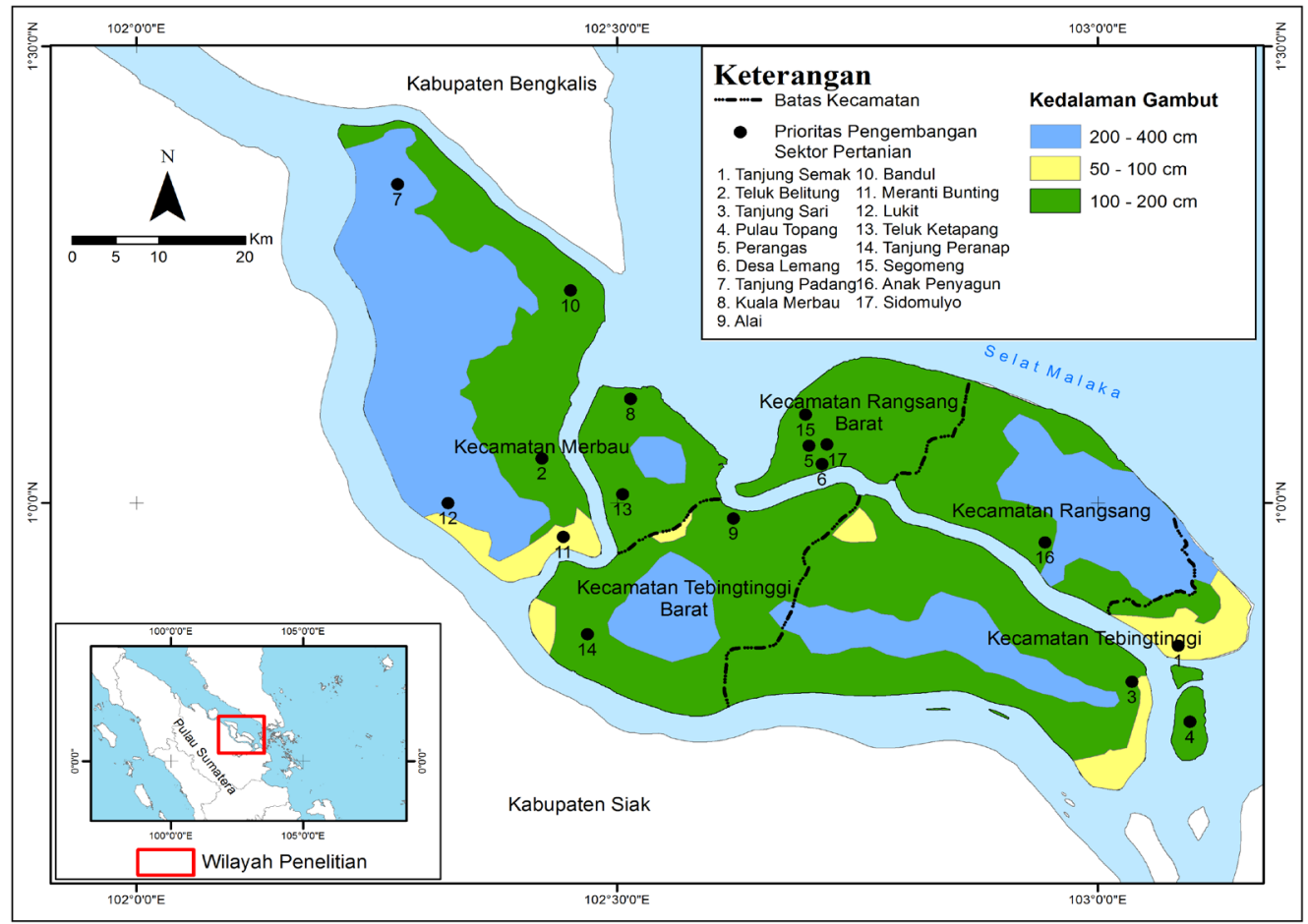

Gambar 5. Prioritas Pengembangan Sektor Pertanian berdasarkan Kondisi Kedalaman Lahan Gambut di Kabupaten Kepulauan Meranti (Wetland International Indonesia, 2002) 
Hasil produk pertanian tersebut (sagu, sawit, karet, akasia) agar memiliki nilai tambah harus dilakukan pengolahan lebih lanjut dalam industri. Oleh karena itu sektor basis berikutnya adalah sektor industri pengolahan. Karena sektor industri pengolahan tersebut berbasis pertanian maka sebaiknya industri pengolahan tersebut dikembangkan berdekatan dengan lokasi lahan pertaniannya dan pada daerah yang telah memiliki infrastruktur publik yang memadai.

Berdasarkan uraian diatas dan dengan menyesuaikan pada Rencana Pembangunan Jangka Panjang (RPJP) Kabupaten Kepulauan Meranti Tahun 2005-2025, secara khusus wilayah pengembangan industri pengolahan adalah sebagai berikut: Selatpanjang, Kecamatan Merbau (industri pengolahan sagu); Tanjung Samak, Kecamatan Rangsang (industri hasil perkebunan kelapa); Tanjung Sari, Kecamatan Tebing Tinggi Timur (industri pengolahan sagu). (BPS Kabupaten Kepulauan Meranti, 2016).

\section{KESIMPULAN}

Penentuan Batam sebagai pusat pertumbuhan yang disebut sebagai Kawasan Perdagangan Bebas dan Pelabuhan Bebas (KPBPB) belum mampu memberikan dampak sebar (spread effect) yang signifikan bagi pembangunan dan kesejahteraan masyarakat di Kabupaten Kepulauan Meranti. Oleh karena itu, Kabupaten Kepulauan Meranti perlu mengembangkan spesialisasi produksi yang dapat menjadi leading sector (sektor basis) dalam wilayahnya. Sektor basis tersebut adalah: 1). Sektor tansportasi dan pergudangan; 2). Sektor pertanian dan 3). Sektor industri pengolahan.

Adapun sektor basis yang dapat dikembangkan di kabupaten tersebut adalah sektor transportasi dan pergudangan; sektor pertanian, kehutanan dan perikanan; dan sektor industri pengolahan. Sektor transportasi dan pergudangan dapat dikembangkan di daerah Lukit, Tanjung Padang dan Tanjung Sari. Sektor pertanian, kehutanan dan perikanan dapat dikembangkan di Tanjung Samak, Kecamatan Rangsang (kelapa, karet, sagu); Teluk Belitung, Kecamatan Merbau (sagu, karet dan perikanan); Tanjung Sari dan Pulau Topang, Kecamatan Tebing Tinggi Timur (sagu, karet dan perikanan); Perangas dan Desa Lemang, Kecamatan Rangsang Barat (sagu dan karet); Tanjung Padang, Kecamatan Merbau (sagu); Kuala Merbau, Kecamatan Merbau (sagu dan karet); Alai, Kecamatan Tebing Tinggi Barat (sagu dan karet); Bandul (sagu dan karet); Meranti Bunting, Kecamatan Merbau (sagu, karet, kelapa dan perikanan); Lukit, Kecamatan Merbau bagian selatan (sagu); Teluk Ketapang, Kecamatan Merbau (sagu dan karet); Tanjung Peranap, Kecamatan Tebing Tinggi Barat (sagu, karet); Segomeng, Kecamatan Rangsang Barat (sagu dan karet); Sidomulyo dan Anak Penyagun (karet dan kelapa). Sedangkan sektor industri pengolahan dapat dikembangkan di Selatpanjang, Kecamatan Merbau (industri pengolahan sagu);
Tanjung Samak, Kecamatan Rangsang (industri hasil perkebunan kelapa); Tanjung Sari, Kecamatan Tebing Tinggi Timur (industri pengolahan sagu).

\section{DAFTAR PUSTAKA}

Agus, F. dan Subiksa, I.G.M. (2008). Lahan Gambut: Potensi untuk Pertanian Aspek Lingkungan. Bogor: Balai Penelitian Tanah dan World Agroforestry Centre (ICRAF).

Bere, R.C., Otoiu, A., Bucerzan, I. (2014). Determinants of Economic Growth in Cities Acting as Growth Poles in Regions from Romania. Procedia Economics and Finance, 10, 357-365

BPS Kabupaten Kepulauan Meranti. (2016). Sensus Ekonomi 2016 Analisis Hasil Listing Potensial Ekonomi Kabupaten Kepulauan Meranti. Tebing Tinggi: Badan Pusat Statistik Kabupaten Kepulauan Meranti.

BPS Provinsi Riau. (2017). Provinsi Riau dalam Angka 2017. Pekanbaru: Badan Pusat Statistik Provinsi Riau.

Djaenudin, D., Hendrisman, M., Hidayat, A., dan Subagyo, H. (2003). Petunjuk Teknis Evaluasi Kesesuaian Lahan untuk Komoditas Pertanian. Bogor: Balai Penelitian Tanah.

Hidayat, M., Darwin, R. (2017). Analisis Sektor Unggulan dan Pengembangan Wilayah di Kabupaten Kepulauan Meranti, Media Trend, 12, 156-167

Hirschman, A.O. (1958): The Strategy of Economic Development. New Haven: Yale University Press.

Kartono, H., Rahardjo, S., Sandy, I. (1998). Esensi Pembangunan Wilayah, Jakarta: Geografi FMIPA UI.

Miller, M.M., Gibson, L.J., Wright, N.G. (1991). Location Quotient: A Basic Tool for Economic Development Analysis, Economic Development Review, 9, 65-68.

Morrissey, K. (2014). Producing Regional Production Multipliers for Irish Marine Sector Policy: A Location Quotient Approach. Ocean \& Coastal Management, 91, 58-64.

Myrdal, G. (1957). Economic Theory and Underdeveloped Areas. London: Duckworth.

Nagle, G. (2000). Advanced Geography, New York: Oxford University Press.

Potter, R.B. (1985). Urbanisation and Planning in the $3^{\text {rd }}$ world: Spatial Perceptions and Public Participation. Great Britain: Biddles Ltd.

Putra, M., Giyarsih, S.R., Kurniawan, A. (2017). Sektor Unggulan dan Interaksi Wilayah pada Kawasan Strategis Nasional Perkotaan MEBIDANGRO. Jurnal Wilayah dan Lingkungan , 5, 181-187.

Sheppard, E. (2017). Economic Theory and Underdeveloped Regions. Regional Studies, 51, 972-973.

Sjafrizal. (2014). Perencanaan Pembangunan Daerah Dalam Era Otonomi, Jakarta: Rajawali Pers 
Silveira, P., Dentinho, T.P. (2018). A Spatial Interaction Model with Land Use and Land Value. Cities, 78, 60-66.

Sink, T. (2010), Encyclopedia of Geography. SAGE Publications. <http://www.sage-ereference.com/ geography/Article_n538.html $>$.

Syahza, A., Suarman. (2013). Strategi Pengembangan Daerah Tertinggal dalam Upaya Percepatan Pembangunan Ekonomi Pedesaan. Jurnal Ekonomi Pembangunan, 14, 126-139.

Wijaya, G.H. (2012). Perencanan Pembangunan Hutan Kota di Kota Selatpanjang, Kabupaten Kepulauan Meranti, Provinsi Riau. Bogor: Fakultas Kehutanan. Institut Pertanian Bogor. 